\title{
Perlindungan Hukum Terhadap Korban Kekerasan Dalam Rumah Tangga dalam Putusan Pengadilan Negeri Sebagai Implementasi Hak-Hak Korban
}

\author{
Hamidah Abdurrachman \\ Fakultas Hukum Universitas Pancasakti Tegal Jawa Tengah \\ Jl. Halmahera Km. 1 Tegal Jawa Tengah \\ hamidah.azzahara@gmail.com
}

\begin{abstract}
This research discusses the form of legal protection for domestic violence victim woman in court decision and how is the effort in realizing the legal protection for domestic violence victim woman in Indonesian criminal system This research is a normative juridical using statute approach and case approach. Data collection conducted by literary study and document study, observation, and interview. Analysis is conducted qualitatively to obtain proper conclusion from the observed problem. This research found that some judge decisions show the absent of legal protection for domestic violence victim, because judge still imposed the decision merely based on statement in Acts and only imposed punishment to the perpetrator.
\end{abstract}

Key words: Legal protection, victim, domestic violence, state court judge's decision

\begin{abstract}
Abstrak
Penelitian ini mengkaji bentuk perlindungan hukum bagi perempuan korban kekerasan rumah tangga dalam putusan pengadilan dan bagaimana upaya mewujudkan perlindungan hukum bagi perempuan korban kekerasan rumah tangga dalam sistem peradilan pidana di Indonesia. Penelitian ini adalah penelitian yuridis normatif dengan menggunakan pendekatan perundang-undangan (statute approach), dan pendekatan kasus (case approach. Pengumpulan data dilakukan dengan studi kepustakaan, studi dokumen, observasi, dan wawancara. Analisis dilakukan secara kualitatif untuk mendapatkan kesimpulan sesuai dengan permasalahan yang diteliti. Penelitian ini menemukan beberapa putusan hakim menunjukkan belum adanya perlindungan hukum terhadap korban kekerasan dalam rumah tangga karena hakim masih mendasarkan putusannya semata-mata berdasarkan bunyi pasal dalam undangundang serta hanya menjatuhkan hukuman kepada pelaku.
\end{abstract}

Kata kunci : Perlindungan hukum, korban, kekerasan dalam tumah tangga, putusan hakim 


\section{Pendahuluan}

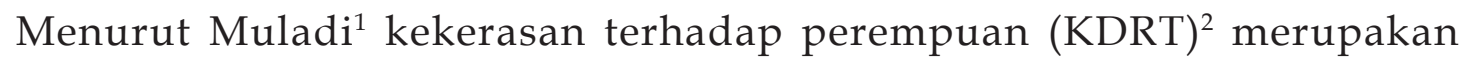
rintangan terhadap pembangunan karena kekerasan dapat menimbulkan akibat kumulatif yang tidak sederhana, seperti dapat mengurangi kepercayaan diri perempuan, menghambat kemampuan perempuan berpartisipasi, mengganggu kesehatan perempuan, mengurangi otonomi baik dalam bidang ekonomi, politik, sosial, dan budaya. KDRT merupakan masalah yang cukup menarik untuk diteliti mengingat angka KDRT yang dilaporkan menunjukkan peningkatan dari tahun ke tahun.

Komisi Nasional (Komnas) Perempuan memaparkan catatan tahunan tentang kekerasan terhadap perempuan menunjukkan peningkatan jumlah kasus secara konsisten dan signifikan. ${ }^{3}$ Alasan lainnya adalah KDRT memiliki keunikan dan kekhasan karena kejahatan ini terjadi dalam lingkup rumah tangga dan berlangsung dalam hubungan personal yang intim, yaitu antara suami dan isteri, orang tua dan anak atau antara anak dengan anak atau dengan orang yang bekerja di lingkup rumah tangga yang tinggal menetap. KDRT yang terjadi antara suami isteri dilandasi oleh hubungan dalam lembaga perkawinan yang di atur pula oleh Kitab Undang-undang Hukum Perdata atau Undang-Undang Nomor 1 Tahun 1974 tentang Perkawinan. Kedudukan pelaku dan korban yang sedemikian ini menyebabkan KDRT masih dipandang sebagai bagian dari hukum privat sehingga penyelesaian kasus ini lebih sering diarahkan untuk damai atau diselesaikan secara internal keluarga.

Lahirnya Undang-Undang Penghapusan Kekerasan Dalam Rumah Tangga merupakan keharusan bagi Indonesia sebagai negara yang telah meratifikasi beberapa konvensi internasional tentang perempuan, seperti Anggota Konvensi CEDAW (Convention on the Elimination of All forms of Discrimination against women) atau Konvensi Tentang Penghapusan Segala Bentuk Diskriminasi Terhadap Perempuan melalui Undang-Undang Nomor 7 Tahun 1984. Undang-Undang Phlm. 40 .

${ }^{1}$ Muladi, Demokrasi, Hak Asasi Manusia, dan Reformasi Hukum di Indonesia, The Habibie Center, Jakarta, 2002,

${ }^{2}$ Pasal 1 Deklarasi Penghapusan Kekerasan terhadap Perempuan, kekerasan terhadap perempuan adalah setiap tindakan berdasarkan perbedaan jenis kelamin (gender-based violence) yang berakibat atau mungkin kesengsaraan atau penderitaan perempuan secara fisik, seksual atau psikologis, termasuk ancaman tindakan tertentu, pemaksaan atau perampasan kemerdekaan secara sewenang-wenang, baik yang terjadi di depan umum atau dalam kehidupan pribadi.

${ }^{3}$ Kompas, 8 Maret 2006, hlm. 13

${ }^{4}$ Suara Merdeka, 12 Desember 2005, hlm. 2 
KDRT memiliki nilai strategis bagi upaya penghapusan kekerasan terhadap perempuan. Pertama, dengan diundangkannya UU P-KDRT akan menggeser isu KDRT dari isu privat menjadi isu publik. Dengan demikian diharapkan dapat meruntuhkan hambatan psikologis korban untuk mengungkap kekerasan yang diderita dengan tanpa dihantui perasaan bersalah karena telah membuka aib. Kedua, UU KDRT akan memberi ruang kepada negara untuk melakukan intervensi terhadap kejahatan yang terjadi di dalam rumah sehingga negara dapat melakukan perlindungan lebih optimal terhadap warga negara yang membutuhkan perlindungan khusus (perempuan dan anak) dari tindak kekerasan. Ketiga, UU PKDRT akan berpengaruh pada percepatan perwujudan kebijakan toleransi nol kekerasan terhadap perempuan yang digulirkan pemerintah beberapa tahun lalu.

Dalam penegakan hukum terhadap Undang-Undang P-KDRT terdapat sejumlah kendala: Pertama, delik KDRT yang dirumuskan dalam UU P-KDRT “setengah hati” sehingga dalam pelaksanaan hampir semua bentuk KDRT dianggap delik aduan dan "mentok" sebagai kekerasan yang tidak menimbulkan akibat (secara fisik); Kedua, bias persepsi penegak hukum sejak tahap awal terhadap KDRT sehingga KDRT seringkali dianggap sebagai persoalan privat dan kurang mendapat prioritas; Ketiga, penegak hukum cenderung melihat KDRT adalah kekerasan fisik sehingga pembuktian terhadap dampak kekerasan hanya dilihat kasat mata saja padahal KDRT selalu menimbulkan dampak ganda, keempat, perlindungan hukum yang dirumuskan dalam UU P-KDRT dalam pelaksanaannya terhambat karena secara teknis belum ada persamaan persepsi penegak hukum, kelima, paradigma hukum pidana yang bergerak hanya antara perbuatan dan orang dan belum menyentuh korban mengakibatkan kedudukan korban dalam sistem peradilan pidana masih belum diperhatikan.

Dampak lebih luas yang diakibatkan oleh hal tersebut adalah hak-hak korban terbaikan. Harkristuti menilai terdapat sejumlah kendala dalam proses peradilan pidana atas tindakan kekerasan domestik terhadap perempuan antara lain karena dalam proses peradilan pidana terdapat sejumlah masalah seperti: (a) kesulitan untuk mendapat keterangan saksi, karena keengganannya untuk terlibat dalam proses peradilan; (b) terbatasnya pemahaman dan keahlian penegak hukum dalam menangani kasus tindak kekerasan pada perempuan; (c) paradigma pembuktian yang mendasarkan pada asas unus testis nullus testis (satu saksi bukan saksi) kecuali dalam kekerasan yang terjadi dalam lingkup rumah tangga dibenarkan 1 saksi namun 
harus dilengkapi dengan pengakuan si pelaku (d) kurang dilibatkannya para pekerja sosial secara intensif dalam penanganan kasus tindak kekerasan terhadap perempuan. $^{5}$

\section{Rumusan Masalah}

Pertama, bagaimana bentuk perlindungan hukum bagi perempuan korban kekerasan rumah tangga dalam putusan hakim? Kedua, bagaimana upaya mewujudkan perlindungan hukum bagi perempuan korban kekerasan rumah tangga dalam sistem peradilan pidana di Indonesia?

\section{Tujuan Penelitian}

Pertama, mengkaji dan menganalisis bentuk perlindungan hukum terhadap perempuan korban kekerasan rumah tangga dalam putusan Pengadilan Negeri. Kedua, mengajukan konsep upaya perlindungan hukum bagi perempuan korban kekerasan rumah tangga dalam sistem peradilan pidana di Indonesia khususnya dalam putusan Pengadilan Negeri.

\section{Metode Penelitian}

Penelitian ini menggunakan beberapa pendekatan, ${ }^{6}$ yaitu pendekatan perundang-undangan (Statute Approach) dilakukan dengan menelaah semua undangundang dan regulasi yang bersangkut paut dengan perlindungan korban dan KDRT. Pendekatan kedua adalah pendekatan Kasus (Case Approach) dengan cara melakukan telaah terhadap kasus-kasus KDRT yang telah menjadi putusan Pengadilan yang telah mempunyai kekuatan hukum yang tetap. Kajian pokok dalam pendekatan ini adalah ratio decidendi atau motivering yaitu pertimbangan hakim untuk sampai kepada putusan. Teknik Pengumpulan Data dalam penelitian ini menggunakan tiga teknik utama, yaitu studi dokumen, observasi, dan wawancara. Hasil penelitian dianalisis secara kualitatif, dimulai dengan menelaah seluruh data yang tersedia dari berbagai

\footnotetext{
${ }^{5}$ Harkristuti Harkrisnowo, "Tindakan Kekerasan Terhadap Perempuan dalam Perspektif Sosio- Yuridis", Jurnal Hukum IUS QULA IUSTUM No. 14 Vol. 7 - 2000, hlm. 165-166.

${ }^{6}$ Peter Mahmud Marzuki, Penelitian Hukum, Kencana, Jakarta, 2006 hlm. 93-95. Lihat juga Johnny Ibrahim, Teori dan Metodologi Penelitian Hukum Normatif, Bayumedia Publishing, Malang, 2006, hlm. 299-322.
} 
sumber, yaitu dari wawancara dan pengamatan yang sudah dituliskan dalam catatan lapangan, dokumen pribadi, dokumen resmi, gambar, foto, dan sebagainya, ${ }^{7}$ melalui prosedur analisis data yaitu redukasi data, unitisasi data, kategorisasi data, dan interpretasi data. ${ }^{8}$

\section{Hasil Penelitian dan Pembahasan}

\section{Perlindungan Korban KDRT Dalam Putusan Pengadilan Negeri}

Untuk melihat bagaimana perlindungan hukum terhadap korban KDRT dalam putusan Pengadilan Negeri, berikut ini disampaikan beberapa contoh putusan: Putusan Pengadilan Negeri Klaten Nomor: 238/Pid.B/2004/PN.Klt dalam perkara Penganiayaan terhadap Isteri dengan terdakwa Irwan Anis Mahsun

Jaksa Penuntut Umum mengajukan terdakwa di persidangan dengan dakwaan tunggal yaitu melanggar Pasal 356 ayat (1) KUHP, dengan tuntutan: menyatakan terdakwa (Irwan Anis Mahsun), terbukti secara sah dan meyakinkan melakukan tindak pidana penganiayaan terhadap isteri sebagaimana dalam dakwaan Pasal 356 ayat (1) KUHP, menjatuhkan pidana terhadap Terdakwa selama 3 (tiga) tahun. Pertimbangan hakim: Pertama, berdasarkan fakta-fakta diperoleh di persidangan dari keterangan saksi-saksi maupun terdakwa serta barang bukti yang diajukan Penuntut Umum terungkap fakta-fakta, terdakwa Irwan Anis Mahsun, telah membakar saksi korban Rikha Nia Januanita, dengan minyak tanah; Kedua, berdasarkan hasil Visum et Repertum serta melihat keadaan korban Rikha Nia Januanita, sebelum dibakar dan sesudah dibakar, benar saksi korban Rikha Nia Januanita mengalami luka berat akibat perbuatan terdakwa; Ketiga, Majelis Hakim Pengadilan Negeri Klaten dalam putusannya menyatakan terdakwa Irwan Anis Mahsun, telah terbukti secara sah dan meyakinkan bersalah melakukan “Kejahatan" dengan sengaja melukai berat istrinya dan menjatuhkan pidana terhadap terdakwa Irwan Anis Mahsum, dengan pidana penjara selama 9 (sembilan) tahun.

\footnotetext{
${ }^{7}$ Lexy J. Moleong, Metode Penelitian Kualitatif, Rosdakarya, Bandung, 1998, hlm.37.

${ }^{8}$ Soerjono Soekanto, Kesadaran Hukum dan Kepatuhan Hukum, CV. Rajawali. Jakarta, 1982, hlm 37.
} 


\section{Putusan Pengadilan Negeri Bandung Nomor: 956/Pid/B/2005/PN.Bdg}

Terdakwa Dadang Iskandar, di ajukan ke Pengadilan Negeri Bandung karena didakwa tindak pidana " penganiayaan yang menyebabkan orang lain meninggal dunia" berdasarkan Pasal 351 KUHP, meskipun pada awalnya terdakwa diajukan dengan menggunakan Undang-Undang RI No. 23 Tahun 2004 tentang Penghapusan Kekerasan dalam Rumah Tangga.

Pertimbangan hakim: Pertama, dari bukti-bukti yang diajukan dalam Persidangan tidak satu alat bukti yang menunjukkan bahwa antara Terdakwa dengan korban terikat secara hukum dan sah sebagai suami istri, sebagaimana dikemukakan Penuntut Umum dalam dakwaannya sehingga karena unsur dalam rumah tangga tidak terpenuhi; Kedua, terhadap dakwaan pertama subsidair dimana terdakwa didakwa melanggar Pasal 338 KUHP tidak terpenuhi, karena tidak ditemui satu alat bukti tentang niat Terdakwa membuat korban meninggal dunia dan tidak pula ditemui alat bukti yang menunjukkan perbuatan terdakwa melempar pisau sangkut ke bagian vital tubuh korban yang dapat menyebabkan korban meninggal dunia; Ketiga, perbuatan Terdakwa melanggar Pasal 351 ayat (3) berdasarkan keterangan saksi-saksi maupun dari keterangan terdakwa dan barang bukti pisau sangkur, serta visum et repertum telah ternyata korban mengalami luka dibagian pinggang yang menurut terdakwa luka tersebut adalah akibat dari pisau sangkur miliknya yang dilemparkannya ke tembok dimana korban berada dibawahnya. Menurut majelis hakim, seharusnya terdakwa mengerti bahwa akibat pisau yang dilemparkannya ketembok, besar kemungkinannya akan mengenai korban yang berada dibawahnya dan nyatanya pisau tersebut telah mengenai korban di bagian pinggang sehingga akibatnya korban mengalami luka dan kemudian bahkan meninggal dunia; Keempat, Majelis Hakim Pengadilan Negeri Bandung dalam putusannya menyatakan terdakwa Dadang Iskandar bin Ucup Suryana telah terbukti secara sah dan menyakinkan bersalah melakukan tindak pidana "Penganiayaan yang menyebabkan orang lain meninggal dunia"; dan menjatuhkan Pidana kepada Terdakwa tersebut dengan pidana penjara selama 6 (enam) tahun;

\section{Putusan Pengadilan Negeri Tapaktuan Nomor : 19/Pid.B/2005/PN.TTN}

Dalam perkara pidana ini, terdakwa H.T. Arbet Bin T. Banta pada hari Rabu, 10 Nopember 2004 bertempat dirumahnya di Lr. Mustakim Desa Kimau Purut, Kota Fajar Kecamatan Kluet Utara, kabupaten Aceh Selatan telah melakukan perbuatan kekerasan fisik terhadap istrinya Hj. Rukmini Binti Hamdani. 
Pertimbangan hakim: Pertama, unsur melakukan perbuatan kekerasan fisik diperoleh berdasarkan keterangan saksi yang dihubungkan dengan alat bukti berupa visum et repertum, terdakwa telah memukul kepala bagian belakang isterinya Hj. Rukmini dengan cara melayangkan tangan kanan yang sudah dikepal sehingga mengenai kepala bagian kiri menyebabkan memar. Rukmini tidak bisa melakukan aktifitas selama 3 hari dan mengalami pusing serta mual akibat pemukulan tersebut; Kedua, selama pemeriksaan tidak ditemukan adanya alasanalasan yang menghapus kesalahan terdakwa baik berupa alasan pembenar maupun pemaaf dan tidak pula terdapat alasan yang menghapus sifat melawan hukum perbuatan oleh karenanya terdakwa harus bertanggung jawab atas perbuatan dan harus dijatuhi pidana; Ketiga, Perbuatan terdakwa telah memenuhi unsur-unsur tindak pidana sebagaimana dimaksud dalam Pasal 44 ayat (1) Undang-Undang Nomor 23 Tahun 2004 tentang Penghapusan Kekerasan Dalam Rumah Tangga; Keempat, terdakwa H.T. Arbet Bin T. Banta tersebut terbukti secara sah dan meyakinkan bersalah melakukan tindak pidana "kekerasan dalam rumah tangga"; menghukum terdakwa dengan pidana penjara selama 3 (tiga) bulan.

Berdasarkan hasil penelitian dalam memutuskan perkara KDRT hakim hanya memutuskan berdasarkan bunyi pasal seperti yang tertulis dalam undang-undang (tekstual). Misalnya, penerapan Pasal 44 Ayat (4) Undang-Undang Nomor 23 Tahun 2004, hakim mengambil kesimpulan dengan mengajukan pertanyaan "apakah setelah dipukul ibu dapat bekerja lagi atau tidak?" Hal ini nampak Putusan Pengadilan Negeri Jakarta Selatan Nomor: 1352/Pid.B/2008/PN.JKT.Sel dimana terdakwa Jeffrey Rusli melakukan perbuatan kekerasan fisik", hakim mempertimbangkan unsur ini terkait dengan pengertian kekerasan fisik menurut Pasal 44 ayat (4) yaitu kekerasan fisik ringan yang tidak menimbulkan penyakit ataupun halangan bagi korban. Kekerasan fisik yang dialami Henny Kentjanawati mengakibatkan luka memar dan rasa sakit, namun rasa sakit tersebut ternyata tidak menjadi penghalang bagi saksi Henny Kentjanawati melakukan aktifitasnya. Hal mana terbukti dari masih dapatnya saksi mengantarkan anaknya ke sekolah serta bertemua dengan saksi N.D. Hariman di Senayan City.

Penafsiran hakim yang demikian ini mengakibatkan putusan pemidanaan yang dijatuhkan sangat ringan (hanya 2 bulan penjara) dan tidak menimbulkan efek jera bagi pelaku, seperti yang dikatakan Cesarre Beccaria dan Jerome Bentham dalam teorinya yaitu Deterrence Theory menekankan pada aspek penghukuman atau pada 
aspek sistem peradilan pidana, yaitu mulai dari perumusan ancaman pidana, proses penyidikan, penuntutan, penegakkan hukum, sampai dengan proses penjatuhan hukuman yang kesemuanya diarahkan terjadinya atau timbulnya efek deterrence atau jera sebagai tujuan utama, hal ini akan mencegah terjadinya tindak kejahatan yang sama untuk berulang. Lebih lanjut dikatakan oleh Beccaria dan Bentham, aspek penghukuman dan sistem pemidanaan tersebut baru bisa efektif dan menimbulkan efek jera (deter) ketika dalam pemidanaan tersebut terdapat unsur-unsur: ancaman sanksi hukuman yang cukup membebani ( severe); ancaman sanksi hukuman yang seimbang (fit) dengan perbuatan jahat yang dilakukan, tidak terlalu berat dan tidak terlalu ringan bila dibandingkan dengan perbuatan yang dilakukannya dan sanksi hukuman harus diberikan dengan segera, yaitu diberikan ketika setelah perbuatan jahat tersebut dilakukan ( celerity) serta adanya unsur kepastian dalam pelaksanaan penghukumannya (certainty).

Masalah penafsiran unsur-unsur perbuatan, yang utama memang penafsiran otentik karena lebih dapat dipertanggung jawabkan secara hukum, sedangkan penggalian nilai-nilai yang ada dalam masyarakat hanya menyangkut perkara yang tidak ada peraturan yang mengatur atau ada ketidakjelasan dalam perundangundangan. Dalam bekerja hakim hanya melaksanakan bunyi undang-undang saja. ${ }^{9}$ Hal ini membuktikan masih kuatnya pandangan legal positivistic yang membelenggu hakim, untuk menegakkan undang-undang dan peraturan yang ada secara tekstual. Padahal "hukum adalah karya manusia yang berupa karya manusia yang berisi petunjuk tingkah laku, merupakan pencerminan dan kehendak manusia tentang bagaimana seharusnya masyarakat dibina dan dibawa ke arah mana. Oleh karena itu hukum mengandung rekaman ide-ide yang dipilih masyarakat dari tempat hukum diciptakan, yaitu ide keadilan. ${ }^{10}$

Menghadapi sikap hakim yang demikian mungkin perlu dipertanyakan dimanakah letak hubungan moral dan hukum? Komariah ${ }^{11}$ menjawab moral rakyat bersembunyi dalam asas-asas hukum, seperti yang dikatakan Scholten asas-asas hukum ada dalam kehidupan batin. Undang-Undang Nomor 23 Tahun 2004 menetapkan asas hukum: penghormatan hak asasi manusia, keadilan dan kesetaraan

\footnotetext{
${ }^{9}$ Wawancara dengan Hakim, Aruminingsih, PN Depok, 15 Juli 2009

${ }^{10}$ Satjipto Rahardjo, Ilmu Hukum, Citra Aditya Bakti, Bandung, 1996, hlm. 18

${ }^{11}$ Komariah Sapardjaya, Ajaran Sifat Melawan Hukum Materil Dalam Hukum Pidana Indonesia, Alumni, Bandung, 2003, hlm. 15
} 
jender, non diskriminasi serta perlindungan hukum, seharusnya di dalam memutuskan perkara KDRT hakim menerapkan asas tersebut dalam keputusannya untuk memberikan hak-hak korban. Sudarto, pernah mengingatkan “...bagaimanapun rasa keadilan yang tersimpan dalam hati nurnai masyarakat harus pula dirasakan hakim dan dipertimbangkan, dalam membuat keputusan, hakim harus meletakkan telinga di dada rakyat agar dapat mendengar detak jantung masyarakat, meskipun tetap harus berada dengan kokohnya diatas landasan hukum"12. Lintong O Siahaan mengatakan dalam memutus perkara hakim berada di antara 2 titik yaitu kepastian hukum dan keadilan (asas kemanfaatan berada di tengahnya) dengan suatu pertimbangan yang nalar, hakim harus menentukan kapan dia berada dekat dengan titik kepatian hukum dan kapan dia berada dekat dengan titik keadilan, dengan mempertimbangkan asas kemanfaatan yang ada. ${ }^{13}$ Idealnya putusan harus memuat idee des Recht, yang meliputi tiga unsur yaitu keadilan (Gerechtigkeit), kepastian hukum (Rechtsicherheit) dan kemanfaatan (Zwechtmassigkeit). Ketiga unsur tersebut semestinya oleh Hakim dipertimbangkan dan diterapkan secara proporsional, sehingga pada gilirannya dapat dihasilkan putusan yang benar-benar memenuhi harapan para pencari keadilan. Dalam praktiknya para hakim punya dalih, apabila pencari keadilan (justiciabellen) tidak puas dengan putusan yang dijatuhkan, mereka dipersilahkan mengajukan upaya hukum yang ada, banding atau kasasi.

\section{Upaya Perlindungan Hukum terhadap Perempuan Korban Kekerasan dalam Rumah Tangga dalam Sistem Peradilan Pidana di Indonesia}

Harus diakui, Undang-Undang Penghapusan Kekerasan Dalam Rumah Tangga merupakan terobosan progressif dalam sistem hukum pidana, tetapi dalam pelaksanaannya masih menitikberatkan pada penghukuman pelaku. Kalau ini terjadi pada suami maka pihak korban (isteri) akan berfikir panjang untuk meneruskan tuntutannya karena relasi suami isteri yang ada diantara mereka. Di samping itu, aparat penegak hukum masih memandang KDRT sebagai delik aduan sehingga selalu diarahkan untuk diselesaikan secara kekeluargaan. Sikap nonreporting korban, khususnya perempuan sangat erat dengan posisi korban sebagai subordinasi dalam

\footnotetext{
${ }^{12}$ Sudarto, Dampak Putusan Hakim Pidana bagi Masyarakat, makalah dalam Seminar "Menuju Sistem Adminstrasi Peradilan Pidana yang Ideal, Universitas Diponegoro, Semarang, 3 November 1984, hlm. 5

${ }^{13}$ Lintong O Sihaan, Peran Hakim Agung Dalam Penemuan Hukum (Rechtsvinding) dan Penciptaan Hukun (Rechtsschepiing)pada Era Reformasi dan Transformasi, Artikel pada Varia Peradilan Nomor 252, 2006.
} 
rumah tangga, yang tidak dengan segera mengambil keputusan meskipun hal tersebut untuk menolong dirinya sendiri. Dalam paktiknya penafsiran hakim terhadap bentuk kekerasan, sangat ditentukan oleh apa yang terlihat saja, sehingga kekerasan psikis juga diukur dengan kondisi fisik korban sehari-hari. Beberapa kendala dalam Penanganan Korban KDRT, meliputi: ${ }^{14}$

Pertama, kasus KDRT yang dilaporkan korban, kerapkali tidak ditindaklanjuti karena korban ragu-ragu atau tidak mengerti bahwa hal yang dilaporkan itu adalah tindak pidana. Demikian halnya terhadap kasus yang telah diproses pihak Kepolisian pun acapkali ditarik kembali dengan berbagai macam alasan, misalnya karena korban merasa sudah memaafkan pelaku, ketergantungan ekonomi terhadap pelaku, KDRT masih dianggap sebagai aib keluarga; Kedua, beda pemahaman antar penegak hukum terhadap bentuk KDRT; tentang mekanisme pemberian perlindungan dan belum semua pihak mendukung upaya perlindungan terhadap korban KDRT; Ketiga, lamanya rentang waktu antara kejadian dan visum, sehingga hasil visum menjadi kurang mendukung terhadap proses hukum; Keempat, masalah penganggaran untuk sosialisasi ke daerah yang sulit dijangkau, sehingga frekuensi tidak memadai, dan pendanaan shelter baik untuk bangunan maupun operasionalnya; Kelima, penanganan kasus KDRT belum dianggap prioritas, sehingga pembentukan PPT masih tersendat; Keenam, substansi pemidanaan sebagaimana dimaksud dalam ketentuan Pasal 44 dan Pasal 49 UU PKDRT belum mengandung efek jera. Dalam beberapa kasus (khusunya KDRT psikis) hakim menjatuhkan pidana cukup ringan karena hanya melihat kondisi luar korban tanpa mencoba menggali penderitaan korban (di dalam).

Dalam putusan hakim yang diteliti, tidak ditemukan adanya pemberian hakhak korban baik berupa ganti rugi atau kompensasi dalam bentuk materi kepada korban atas harm yang mereka alami. Berkaitan dengan masalah kompensasi ini Victimologi melihat salah satu tujuan pengaturan ganti kerugian adalah mengembangkan keadilan kesejahteraan mereka yang menjadi korban, menderita mental, fisik, sosial. Pelaksanaan peraturan ganti kerugian yang baik itu memberikan kemungkinan kepada pihak korban untuk secara leluasa ikut serta menyatakan pendapatnya. Hal ini adalah sangat penting karena menyangkut nasibnya. ${ }^{15}$

\footnotetext{
${ }^{14}$ Mudjiati, "Implementasi Undang-Undang Nomor 23 Tahun 2004 Tentang Penghapusan Kekerasan Dalam Rumah Tangga Suatu Tantangan Menuju Sistem Hukum Yang Responsif Gender”, Jurnal Legislasi Indonesia, Vol. 5 No. 3 September 2008, hlm. 65.

${ }^{15}$ Ika Nurdevi Wibawanti, Relevansi Victimologi Dengan Evaluasi Pengaturan Ganti KerugianTerhadap Korban, www.google.com
} 
Menurut Angkasa, restitusi perlu diintegrasikan ke dalam sistem peradilan pidana. Pein tegrasian ini dengan pertimbangan bahwa restitusi merupakan lembaga pidana yang dapat memberikan manfaat bagi korban, pelaku, negara, dan masyarakat ${ }^{16}$ sebagai penggantian kerugian finansial, perbaikan dan/atau pengobatan atas luka-luka fisik maupun penderitaan psikologis sebagai korban tindak pidana yang telah menimpanya. Restitusi akan sangat berarti, korban tindak pidana saat ini cendrung menjadi korban ganda; Pertama, menjadi korban atas tindak pidana yang menimpanya; Kedua, menjadi korban ketika memasuki sistem peradilan pidana yang paradigmanya masih berorientasi terhadap pelaku. Menurut Schneider, ${ }^{17}$ prosedur restitusi terdapat 5 (lima) cara:

Pertama, model basic restitution dengan prosedur pelaku membayar kepada pengadilan, dan pengadilan kemudian memberikan uang tersebut kepada korban; Kedua, model expanded basic restitution dengan prosedur pelaku dicarikan pekerjaan (bagi pelaku yang berpenghasilan rendah dan pelaku berusia muda); Ketiga, model victim assistance dengan prosedur pelaku diberi kesempatan membantu korban sehingga korban dapat menerima ganti rugi secara penuh; Keempat, model victim assistance-offender accountability demi penyelesaian yang memuaskan kedua belah pihak, dilakukan dengan negosiasi dan kadang-kadang dengan mempertemukan kedua belah pihak; Kelima, model community accountability-deterrence dengan prosedur permintaan ganti rugi dimintakan oleh sekelompok orang sebagai wakil dari masyarakat. Permintaan ganti rugi meliputi jenis pekerjaan yang harus dilakukan, maupun jadwal pembayaran ganti rugi.

Model basic restitution tampaknya yang paling selaras dan tepat untuk dipakai putusan hakim perkara KDRT, dengan membayar melalui pengadilan akan lebih terkontrol, dalam arti menghindarkan dari resiko pemerasan yang dilakukan korban terhadap pelaku maupun pengingkaran kewajiban pelaku untuk membayar restitusi, serta lebih memudahkan dalam penegakan hukumnya apabila terdapat pihak-pihak yang menyalahi.

\footnotetext{
${ }^{16}$ Angkasa, "Kedudukan Korban Dalam Distem Peradilan Pidana”, Disertasi Program Doktor Ilmu Hukum UNDIP Semarang, 2003, hlm. 244.

${ }^{17}$ Andrew Karmen, Crime Victim An Introduction to Victimology, Books/Cole Publishing Company Monterey, California, 1984, hlm, 182
} 


\section{Upaya Perlindungan Hukum terhadap Korban KDRT pada Masa yang akan Datang}

Masalah KDRT, dirumuskan dalam RUU KUHP tahun $2008^{18}$ dalam Bab XXIII, dengan judul Tindak Pidana Terhadap Badan, Bagian Ketiga Kekerasan Dalam Rumah Tangga, terdiri atas tiga paragraph. Pengaturan tindak pidana Kekerasan dalam Rumah Tangga merupakan lompatan mindset yang sangat membanggakan, mengingat masih kentalnya persepsi masyarakat tentang KDRT sebagai persoalan privat yang harus diselesaikan secara internal keluarga. Kriminalisasi KDRT menjadi kejahatan dalam KUHP menunjukkan adanya good will pemerintah untuk melaksanakan amanat Deklarasi Anti Kekerasan terhadap Perempuan. Kriminalisasi (criminalization) adalah proses untuk menjadikan suatu perbuatan yang semula bukan tindak pidana menjadi tindak pidana. Dalam perkembangan selanjutnya kriminalisasi dapat diartikan pula sebagai mengaktualisasikan peraturan hukum pidana agar lebih efektif; juga dapat dikatakan sebagai usaha untuk memperluas berlakunya hukum pidana.

Rumusan kekerasan fisik dalam Pasal 587 RUU KUHP, boleh dikatakan diambil secara keseluruhan dari Undang-Undang Penghapusan Kekerasan Dalam Rumah Tangga. Pengertian kekerasan dalam Pasal 178 RUU KUHP, kekerasan adalah setiap perbuatan penyalahgunaan kekuatan fisik dengan atau tanpa menggunakan sarana secara melawan hukum dan menimbulkan bahaya bagai badan, nyawa, kemerdekaan, penderitaan fisik, seksual, psikologis, termasuk menjadikan orang pingsan atau tidak berdaya. Dalam Undang-Undang Penghapusan Kekerasan Dalam Rumah Tangga, antara kekerasan fisik, psikis, ekonomi dan penelantaran dirumuskan tersendiri mengingat karakteristik masing-masing kekerasan tersebut. Hal lainnya adalah RUU KUHP, mencantumkan ancaman minimum khusus apabila kekerasan fisik tersebut berakibat korban jatuh sakit, luka berat atau mati.

Selanjutnya Pasal 588 RUU KUHP merumuskan tindak pidana kekerasan psikis namun tidak dilengkapi dengan pengertian. Padahal kekerasan psikis dalam UndangUndang kekerasan dalam rumah tangga menyangkut semua tindakan yang berdampak pada psikologis korban, sehingga tindakan tersebut tidak hanya kekerasan fisik semata tetapi dengan perbuatan lain, misalnya melalui perkataan, nama panggilan yang merendahkan, pembatasan ruang gerak, kemerdekaan, dsb. Dalam Pasal 589-590 RUU KUHP tentang kekerasan seksual, juga tidak ditemukan

${ }^{18}$ RUU Kitab Undang-Undang Hukum Pidana, Direktorat Jenderal Peraturan Perundang-undangan, Departemen Hukum dan Hak Asasi Manusia, 2008 
pengertian seperti halnya yang terdapat dalam undang-undang kekerasan dalam rumah tangga. Hanya saja RUU KUHP memberlakukan batas minimum khusus dalam hal terjadinya kekerasan seksual, meskipun ancaman pidana penjara lebih ringan dibanding ancaman yang terdapat dalam undang-undang kekerasan dalam rumah tangga; sedangkan ancaman pidana denda RUU lebih tinggi dibandingkan dengan undang-undang kekerasan dalam rumah tangga. Mengenai kekerasan ekonomi, RUU KUHP memasukkan sebagai tindak pidana menelantarkan orang, yang secara khusus dirumuskan dalam Pasal-pasal 524 RUU KUHP. Dibandingkan dengan undang-undang kekerasan dalam rumah tangga, rumusan tentang kekerasan ekonomi yang mengakibatkan ketergantungan ekonomi tidak ditemukan dalam rumusan RUU KUHP.

Dengan dirumuskannya masalah kekerasan dalam rumah tangga dalam RUU KUHP, merupakan jawaban terhadap pertanyaan yang selama ini berkembang yaitu undang-undang kekerasan dalam rumah tangga belum memiliki "payung hukum" dalam Aturan Umum. Disisi lain pemberlakuan dua hukum tentu akan menimbulkan "kekacauan" dalam penegakan hukum apalagi jika aparat penegak hukum belum memiliki sense terhadap korban khususnya korban kekerasan dalam rumah tangga. Undang-Undang Penghapusan Kekerasan Dalam Rumah Tangga merupakan lex specialis terhadap KUHP sehingga penerapannya sesuai dengan azas lex specialis derogat lex generalis. Dalam hukum pidana, terhadap kedua jenis aturan yang berlaku asas lex specialis derogat lex generalis, dimana ketentuan pidana yang khusus (lex specialis) menghapus (Men-derogat) ketentuan pidana yang umum (lex generalis). Ini berarti kalau suatu persoalan hukum pidana sudah ada ketentuannya yang lebih khusus dalam berbagai UU di luar KUHP, maka ketentuan dalam KUHP dapat dikesampingkan. Dengan asas ini, maka dualisme dalam hukum pidana seharusnya dapat dihilangkan.

Pembaruan hukum pidana yang berorientasi kepada korban (victim oriented) diperlukan sebagai perujudan penyelenggaraan negara hukum Indonesia di mana semua orang memperoleh akses keadilan (bukan hanya pelanggar) dan sebagai kebijakan yang seimbang (balance) dalam pembaruan hukum pidana. Jadi pembaruan hukum pidana tidak mengutamakan perlindungan kepentingan pelanggar saja dan mengabaikan kepentingan korban, atau mengutamakan perlindungan kepentingan korban dan mengabaikan kepentingan pelanggar, meminjam istilah Groenhuijsen, kebijakan terhadap korban tersebut bukan sebagai priority kepada korban saja tetapi parity kepada pelanggar dan korban. 
Perkembangan orientasi hukum pidana, jika semula hukum pidana berorientasi kepada perbuatan (crime) sasarannya adalah prevention of crime, selanjutnya kepada orang (offender) sasarannya adalah treatment of offender, kemudian berkembang kepada korban (victims) sasarannya adalah treatment of victims. Adanya perhatian terhadap korban, sesuai dengan perkembangan dewasa ini agar hukum pidana menghapuskan kesan seolah-olah hanya memanjakan pelaku ketimbang korban. Hal ini merupakan kebutuhan mengingat penderitaan korban kejahatan tidak dihiraukan oleh sistem peradilan pidana. Sisi lain dalam kebijakan terhadap penanggulangan kejahatan melalui sistem peradilan pidana adalah terlalu memfokuskan kepada pelaku kejahatan (offender centered) dan tidak dipikirkannya akibat kejahatan pada diri korban dalam setiap pengambilan keputusan. Korban kejahatan mengalam viktimisasi sekunder yang disebabkan oleh reaksi formal terhadap kejahatan oleh otoritas sistem peradilan pidana.

Perumusan yang lebih konkret tentang perlindungan korban adalah ketentuan Pasal 135 RUU KUHAP yaitu: (1) Apabila terdakwa dijatuhi pidana dan terdapat korban yang menderita kerugian materiel akibat tindak pidana yang dilakukan oleh terdakwa, Hakim mengharuskan terpidana membayar ganti kerugian kepada korban yang besarnya ditentukan dalam putusannya; (2) Apabila terpidana tidak membayar ganti kerugian sebagaimana dimaksud pada ayat (1), harta benda terpidana disita dan dilelang untuk membayar ganti kerugian kepada korban; (3) Apabila terpidana berupaya menghindar untuk membayar kompensasi kepada korban, terpidana tidak berhak mendapatkan pengurangan masa pidana dan tidak mendapatkan pembebasan bersyarat; (4) Dalam penjatuhan pidana bersyarat dapat ditentukan syarat khusus berupa kewajiban terpidana untuk membayar ganti kerugian kepada korban; (5) Ketentuan lebih lanjut mengenai syarat dan tata cara penyitaan dan pelelangan sebagaimana dimaksud pada ayat (2) diatur dengan Peraturan Pemerintah.

Berdasarkan hasil penelitian, otoritas yang diberikan kepada hakim untuk menetapkan ganti kerugian khsususnya dalam tindak pidana KDRT nampaknya akan mengalami kesulitan sehubungan dengan relasi personal sebagai suami isteri yang memiliki harta bersama, sehingga kalau terjadi penyitaan dan pelelangan termasuk juga bagian harta isteri. Seorang Hakim mengatakan ganti kerugian hanya bisa diberikan dalam tindak pidana umum sedangkan dalam KDRT adalah sesuatu yang mustahil dan sulit untuk dilakukan mengingat adanya harta gono gini antara suami isteri. ${ }^{19}$

${ }^{19}$ Wawancara dengan Bapak Jatmiko, Hakim PN Semarang, tanggal 10 Oktober 2009 


\section{Penutup}

Berdasarkan uraian di atas dapat disimpulkan bahwa, Undang-Undang Penghapusan Kekerasan Dalam Rumah Tangga belum mengakomodir hak-hak korban untuk mendapatkan ganti rugi material atas penderitaan yang dialami baik dalam bentuk restitusi maupun kompensasi; hal ini nampak dalam putusan Pengadilan, hakim memutuskan hanya berdasarkan "apa yang tertulis" dalam undang-undang dan tidak memasukkan hak-hak korban sebagai pengganti penderitaan yang dialami. Para pihak terkait antara lain jaksa penuntut umum, penasihat hukum tersangka/terdakwa, saksi (korban) serta hakim dengan didukung alat bukti yang ada, cenderung berpumpun (focus) pada pembuktian atas tuduhan jaksa penuntut umum terhadap tersangka/terdakwa. Proses peradilan lebih berkutat pada perbuatan tersangka/terdakwa memenuhi rumusan pasal hukum pidana yang dilanggar atau tidak. Penafsiran hakim yang demikian ini mengakibatkan putusan pemidanaan yang dijatuhkan cenderung ringan dan sangat bervariasi sehingga tidak menimbulkan efek jera bagi pelaku.

Pembaharuan hukum pidana (formil dan materil) yang berorientasi kepada korban perlu diberi fondasi yang kuat agar kepentingan korban dan masyarakat yang menderita dan dirugikan mendapatkan perlindungan hukum namun mengingat pembaharuan hukum pidana memerlukan proses waktu yang relatif lama sedangkan nasib korban perlu segera mendapat perhatian maka kebijakan penegakan hukum dan keadilan yang berorientasi kepada korban dengan mempertimbangkan perspektif korban dan keadilan restorative perlu difikirkan antara lain melalui perubahan UU Nomor 23 Tahun 2004 tentang Pemberantasan Kekerasan Dalam Rumah Tangga khususnya Pasal 10 berkaitan tentang hak-hak korban.

\section{Daftar Pustaka}

Angkasa, Kedudukan Korban Dalam Sistem Peradilan Pidana, Disertasi Program Doktor Ilmu Hukum UNDIP Semarang, 2003.

Harkrisnowo,Harkristuti, Tindakan Kekerasan Terhadap Perempuan dalam Perspektif Sosio- Yuridis, Artikel dalam Jurnal Hukum IUS QUIA IUSTUM No. 14 Vol. 7 - 2000, Jakarta.

Ibrahim, Johnny, Teori dan Metodologi Penelitian Hukum Normatif, Bayumedia Publishing, Malang, 2006. 
Karmen, Andrew, Crime Victim An Introduction to Victimology, Books/Cole Publishing Company Monterey, California, 1984.

Laporan Kasus kekerasan Berbasis Jender di Jawa Tengah Tahun 2005, Divisi Monitoring LRC- KJHAM, Semarang.

Moleong, Lexy J., Metode Penelitian Kualitatif, Rosdakarya, Bandung, 1998.

Mudjiati, Implementasi Undang-Undang Nomor 23 Tahun 2004 Tentang Penghapusan Kekerasan Dalam Rumah Tangga Suatu Tantangan Menuju Sistem Hukum Yang responsif Gender, Jurnal Legislasi Indonesia, Vol. 5 No. 3 September 2008, Jakarta, 2008.

Muladi, Demokrasi, Hak Asasi Manusia, dan Reformasi Hukum di Indonesia, The Habibie Center, Jakarta, 2002.

Nawawi Arief, Barda, Bunga Rampai Kebijakan Hukum Pidana, Citra Aditya Bakti, Bandung, 1996.

Nurdevi Wibawanti, Ika, Relevansi Victimologi Dengan Evaluasi Pengaturan Ganti Kerugian Terhadap Korban, www.google.com2009.

O Sihaan, Lintong, Peran Hakim Agung Dalam Penemuan Hukum (Rechtsvinding) dan Penciptaan Hukun (Rechtsschepiing)pada Era Reformasi dan Transformasi, Artikel pada Varia Peradilan Nomor 252, Jakarta, 2006.

Rahardjo, Satjipto, Ilmu Hukum, Bandung: Citra Aditya Bakti, Bandung, 1996.

Sapardjaya, Komariah, Ajaran Sifat Melawan Hukum Materil Dalam Hukum Pidana Indonesia, Alumni, Bandung, 2003.

Soekanto, Soerjono, Kesadaran Hukum dan Kepatuhan Hukum, CV. Rajawali, Jakarta, 1982.

Sudarto, Dampak Putusan Hakim Pidana bagi Masyarakat, makalah dalam Seminar "Menuju Sistem Adminstrasi Peradilan Pidana yang Ideal," Universitas Diponegoro, Semarang, 1984.

Widiana,Wahyu, Upaya Penyelesaian Perkara Melalui Perdamaian Pada Pengadilan Agama, Kaitannya Dengan Peran BP4, www. badilag.net, 15 Agustus 2008.

Yayasan Jurnal Perempuan dan The Asia Foundation Indonesia, 2000, Negara dan Kekerasan Terhadap Perempuan, YJP, Jakarta.

Jurnal Perempuan, Nomor 45 Tahun 2006.

Jurnal Perempuan, Nomor 26 Tahun 2006.

Jurnal Hukum, No. 14 Vol. 7 Tahun 2000.

Pro Justitia, tahun XII, nomor 1, Januari 1994.

Kitab Undang-Undang Hukum Pidana.

Undang-Undang Nomor 8 Tahun 1981 tentang Hukum Acara Pidana.

Undang-Undang Republik Indonesia Nomor 23 Tahun 2004 Tentang Penghapusan Kekerasan Dalam Rumah Tangga. 
Undang-Undang Nomor 13 Tahun 2006 tentang Perlindungan Saksi dan Korban.

Undang-Undang Republik Indonesia Nomor 21 Tahun 2007 tentang Penghapusan Tindak Pidana Perdagangan Orang.

RUU Kitab Undang-Undang Hukum Pidana, Direktorat Jenderal Peraturan Perundang-undangan, Departemen Hukum dan Hak Asasi Manusia, 2008.

RUU Kitab Undang-Undang Hukum Acara Pidana, Direktorat Jenderal Peraturan Perundang-undangan, Departemen Hukum dan Hak Asasi Manusia, 2009. 